\title{
Changes in the composition of the excurrent duct system of the rat testis during postnatal development
}

\author{
D. E. Brooks \\ Department of Animal Physiology, Waite Agricultural Research Institute, \\ University of Adelaide, Glen Osmond, South Australia 5064
}

\begin{abstract}
Summary. The gross composition of the testicular excurrent duct system of the rat was examined and compared along the length of the duct and with samples of testis, bladder and liver. Changes in composition with age were examined by analysing tissue from animals at postnatal ages of $19,36,48,60,90$ and 120 days.

In'adult'animals, testicular tissue was characterized by having the lowest dry weight, accompanied by low levels of total protein, lipid, RNA and glycogen; DNA, phospholipids and sialic acid were at levels similar to other tissues. A high proportion of the total protein was soluble. The ductuli efferentes plus initial segment of the epididymis were characterized by high levels of total lipid. The caput epididymidis contained a low level of total protein but a high level of acid-soluble phosphorus. The cauda epididymidis had a low dry weight and low levels of total protein, soluble protein, and lipid, but high levels of acid-soluble phosphorus, DNA and sialic acid. The ductus deferens contained small amounts of RNA and DNA but had a high dry weight, high total protein, soluble protein and glycogen.

Several trends were apparent with increasing age. Dry weight increased in the ductuli efferentes plus initial segment, whilst total protein decreased in the caput and cauda epididymidis. Total lipid increased in the ductuli efferentes plus initial segment and acid-soluble phosphorus and sialic acid increased in all other segments of the excurrent duct system. In all segments the content of RNA and DNA decreased as the animals matured.

The concentration of calcium and magnesium in the excurrent duct system was not significantly different from those levels found in the liver.

High levels of spermine and spermidine were confirmed in the prostate, and were also detected in the testis, caput epididymidis and cauda epididymidis, but at a much lower concentration.
\end{abstract}

\section{Introduction}

It is well known that a number of processes take place during the passage of spermatozoa through the excurrent duct system (EDS) of the testis. These changes become manifest with the development of sperm motility and fertilizing capacity, but the manner of their accomplishment is not yet understood. It is apparent that the epididymis is dependent on androgens to maintain its proper function (Orgebin-Crist, 1973), even to the extent of possessing a specific mechanism for concentrating androgens from fluid leaving the testis (French \& Ritzén, 1973).

Furthermore, the epididymis maintains a luminal fluid of a rather distinct character. This fluid has a low ionic strength, being particularly deficient in $\mathrm{NaCl}$ but with high levels of $\mathrm{K}^{+}$(Crabo, 1965; Levine \& Marsh, 1971). The low ionic strength seems to be compensated by the presence of high concentrations of some organic molecules, in particular carnitine and glycerylphosphorylcholine (GPC) (Dawson, Mann \& White, 1957; Dawson \& Rowlands, 1959; Marquis \& Fritz, 1965; Brooks, Hamilton \& Mallek, 1974). Sialic acid has also been measured in high amounts in the epididymis (Fournier, 1966; Peyre \& Laporte, 1966; Bose, Kar \& Dasgupta, 1966; Rajalakshmi \& Prasad, 1969), and a number of enzymes, e.g. some glycosidases, are present at unusually high levels (Conchie \& Mann, 1957; Conchie, Findlay \& Levvy, 1959). 
As an adjunct to previous work concerning carnitine and GPC (Brooks et al., 1974), the present study set out to examine the gross composition of the excurrent duct system. The work was aimed at studying the composition in two dimensions, firstly with respect to changes along the length of the duct, and secondly with respect to changes at any part of the duct system from the prepubertal state through puberty to the adult. In addition, analyses were made of testis, smooth muscle (bladder) and liver from adult animals in order to provide a further basis for comparison.

\section{Materials and Methods}

Chemicals were of analytical reagent grade where available and solvents were redistilled before use. Orcinol was purified by recrystallization from benzene. Moulding Araldite was obtained from CIBA Company Pty Ltd, Sydney, Australia.

Male hooded Wistar rats were weaned at 18 days of age and housed in the absence of females at $25^{\circ} \mathrm{C}$ with alternate periods of $12 \mathrm{hr}$ light and darkness. The animals were fed freely with 'special mouse cubes' from Charlicks Feeds, Adelaide, South Australia, and had free access to water.

Tissue samples were analysed from animals at various stages during the prepubertal (19 and 36 days of age), pubertal ( 48 and 60 days) and postpubertal ( 90 and 120 days) periods. Spermatozoa first entered the epididymis at about 50 days of age. Animals were killed by decapitation and the EDS was removed and trimmed of excess fat. The tissue was divided into four components-the ductuli efferentes plus the initial segment of the epididymis (DE+IS), caput epididymidis (caput), cauda epididymidis (cauda), and ductus deferens (DD). The location of the cuts to divide the tissue into these four regions has been described previously (Brooks et al., 1974). Tissues were weighed on a torsion balance; tissues from young animals were pooled for analysis. Samples of testis, liver and bladder were also taken from adult animals ( 90 days old) for purposes of comparison. Dry weight was determined by wrapping samples of tissue in a pre-weighed piece of aluminium foil, drying at $110^{\circ} \mathrm{C}$, cooling in a vacuum desiccator and re-weighing.

Protein was estimated by the procedure of Lowry et al. (1951) using a standard of bovine serum albumin. Samples of tissue were dispersed in $4 \mathrm{ml} \mathrm{0.25} \mathrm{M}$-sucrose at $0^{\circ} \mathrm{C}$ in a Potter-Elvehjem homogenizer and centrifuged for $60 \mathrm{~min}$ at $110,000 \mathrm{~g}$. The supernatant was analysed directly as representing soluble protein. The precipitate, representing insoluble protein, was solubilized by heating at $60^{\circ} \mathrm{C}$ with $1 \mathrm{ml} 1 \mathrm{M}-\mathrm{NaOH}$ before assay.

The fractionation of tissue components for phosphorus analysis was based on the procedure of Schmidt \& Thannhauser (1945) incorporating some suggestions of Munro \& Fleck (1966).

The fractions representing acid-soluble material, lipids, RNA, and DNA were incinerated and assayed for phosphorus by the method of Chen, Toribara \& Warner (1956). The amounts of RNA, DNA and phospholipid were determined by multiplying the values for the phosphorus estimations by $10 \cdot 6,10 \cdot 1$, and 25 respectively. In addition, as a check for the phosphorus analysis, the RNA fraction was analysed for pentose (Drury, 1948) and the DNA fraction for deoxypentose (Giles \& Myers, 1965). A 20-ml aliquot from the lipid fraction was used for the determination of total lipid by gravimetric analysis after drying and partitioning by the method of Bligh \& Dyer (1959).

Glycogen was estimated in tissues from animals which were dissected under ether anaesthesia. As much fat as possible was dissected away without rupturing any major blood vessels. The segments of tissue were then rapidly excised and transferred to the extracting tube containing $0.5 \mathrm{ml} 40 \%$ $\mathrm{KOH}$ at $100^{\circ} \mathrm{C}$. The weights of samples of testis, liver and bladder were determined by difference in weight before and after addition of the tissue to the extraction tube. In the case of tissue from the EDS, weights were taken from the contralateral side which could be dissected at leisure and properly freed from fat before weighing. After digestion the tubes were cooled and $0.2 \mathrm{ml} 2 \% \mathrm{Na}_{2} \mathrm{SO}_{4}$ added followed by $1.4 \mathrm{ml}$ ethanol. After standing overnight at $-20^{\circ} \mathrm{C}$ the tubes were centrifuged and the supernatant discarded. The precipitate was washed by resuspension in $0.5 \mathrm{ml} 66 \%$ ethanol and, after centrifugation and removal of the supernatant, the precipitate was dried under a stream of $\mathrm{N}_{2}$ at $45^{\circ} \mathrm{C}$. The glycogen was then brought into solution by treatment with $1 \mathrm{ml} 10 \%$ TCA and aliquots taken for analysis by the method of Scott \& Melvin (1953) using glucose as the standard. 
Total sialic acid was extracted and estimated by the procedure of Warren (1959) using the correction for colour formation from deoxyribose. $\mathrm{N}$-acetylneuraminic acid was used as a standard.

Calcium and magnesium were determined by atomic absorption spectrometry. Tissues were digested in Kjeldahl flasks with $1 \mathrm{ml}$ fuming $\mathrm{HNO}_{3}$ plus two drops of $30 \% \mathrm{H}_{2} \mathrm{O}_{2}$; a further $1 \mathrm{ml}$ $\mathrm{HNO}_{3}$ was added after the samples had gone dry and digestion was continued again until dryness. The residue was taken up in $1 \mathrm{ml} 5 \%$ lanthanum oxide in $1 \mathrm{M}-\mathrm{HCl}$ and further diluted with $4 \mathrm{ml}$ water. The standard solutions of $\mathrm{CaCl}_{2}$ and $\mathrm{MgCl}_{2}$ contained equivalent concentrations of lanthanum oxide and $\mathrm{HCl}$.

Polyamines were extracted by the method of Pegg, Lockwood \& Williams-Ashman (1970) based on that of Raina (1963). Spermine and spermidine were separated by electrophoresis on Whatman No. 1 at $300 \mathrm{~V}$ for $2 \mathrm{hr}$ in $0.1 \mathrm{M}$-citrate adjusted to $\mathrm{pH} 3.5$ with $1 \mathrm{M}-\mathrm{NaOH}$. Spots were visualized with ninhydrin and the colour quantified after elution (Pegg et al., 1970). Spermine and spermidine were also identified on similar electrophoretograms by staining with amido black (Raina, 1963).

The results were analysed by a two-way analysis of variance adapted for samples which contained unequal numbers of replicates (in most cases each mean represented four replicates). In all cases a significant interaction was found between age and segment of the EDS. Using the error mean square from the analysis, a $t$ test was applied in order to test for significant differences between individual means.

\section{Results}

The pattern of body weight change (Text-fig. 1a) indicated that the animals continued to grow over the time span studied. The increase in testis weight followed that of body weight very closely. Segments of the EDS also showed a continual increase in weight to 120 days (Text-fig. 1b), but the caput and cauda showed a much greater increase in size relative to that measured at 19 days of age than did the DE+IS or DD.

The results for the biochemical composition of the EDS were analysed in terms of differences between the segments of the EDS and of changes occurring with age in any particular segment of the duct system. The results are listed in Table 1. In many instances, significant differences were also present between non-adjacent means in the table. For comparative purposes the biochemical composition of testis, bladder and liver is listed in Table 2.
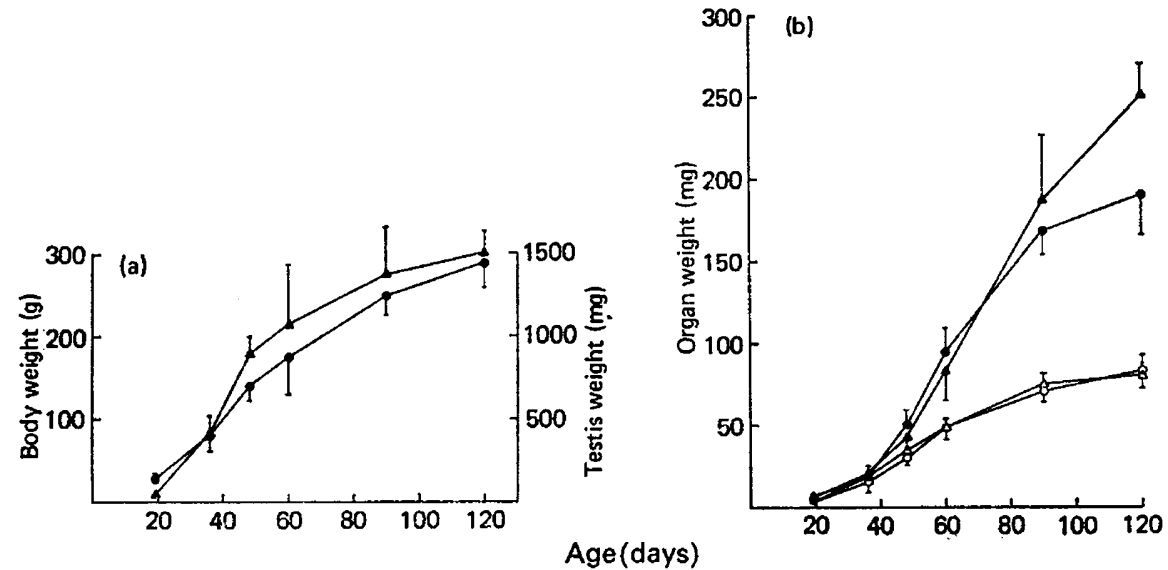

Text-fig. 1. Weight changes during postnatal development of the rat. Each point represents a mean and the S.D. is indicated by a vertical bar. (a) $\bullet$, body weight; $\boldsymbol{\Delta}$, testis weight. (b) $\circ$, ductuli efferentes plus initial segment; $\bullet$, caput epididymidis; $\boldsymbol{\Lambda}$, cauda epididymidis; $\Delta$, ductus deferens. 
Table 1. The biochemical composition of the different segments of the excurrent duct system of the rat testis during postnatal development

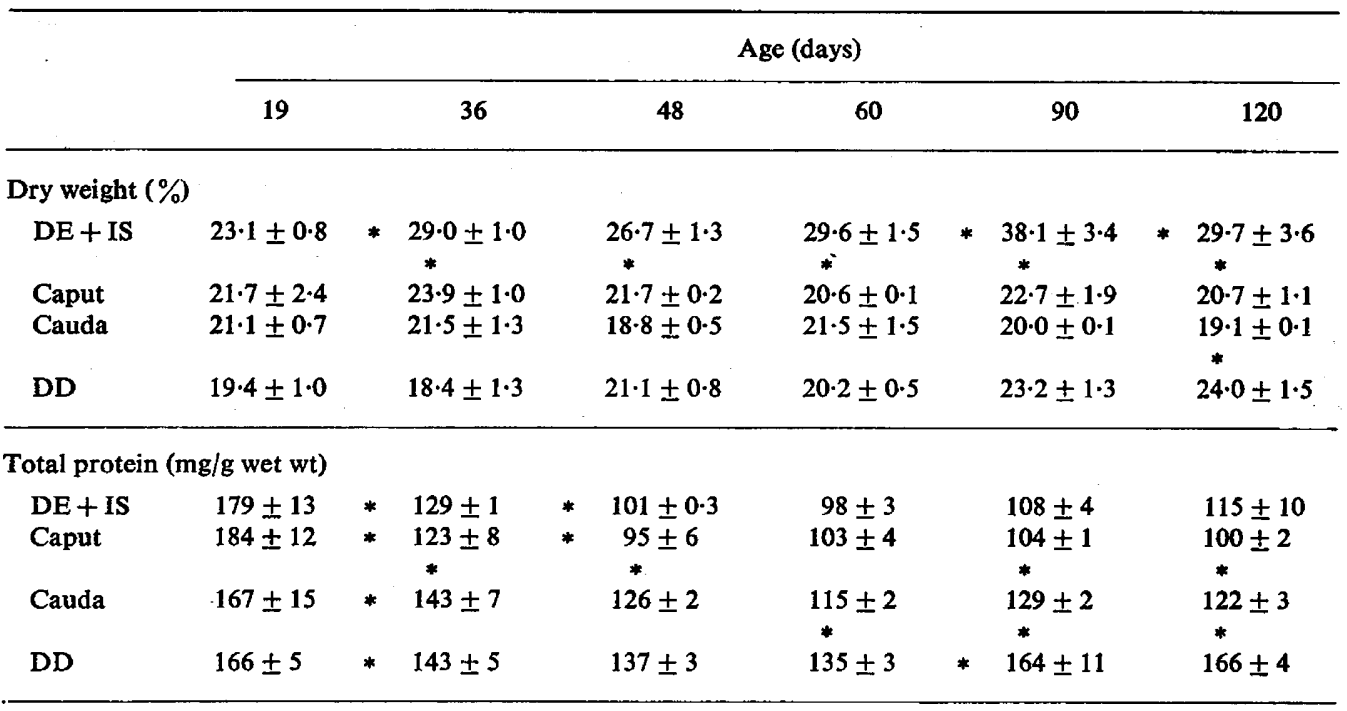

\section{Soluble protein ( $\%$ of total protein)}

\begin{tabular}{|c|c|c|c|c|c|c|c|}
\hline $\mathrm{DE}+\mathrm{IS}$ & $25 \cdot 2 \pm 2 \cdot 5$ & & $\begin{array}{l}25 \cdot 5 \pm 0.4 \\
*\end{array}$ & $\begin{array}{c}33.9 \\
*\end{array}$ & $\begin{array}{c}* 37.2 \pm 0.6 \\
*\end{array}$ & * $31.8 \pm 1.5$ & $30 \cdot 5 \pm 1 \cdot 2$ \\
\hline Caput & $\begin{array}{c}26.9 \\
*\end{array}$ & * & $29 \cdot 1 \pm 1 \cdot 0$ & $\begin{array}{c}37.2 \pm 1.6 \\
*\end{array}$ & $34.9 \pm 0.9$ & $\begin{array}{l}30.5 \pm 0.9 \\
*\end{array}$ & $\begin{array}{c}31.9 \pm 0.6 \\
*\end{array}$ \\
\hline Cauda & $\begin{array}{l}23 \cdot 1 \pm 1 \cdot 7 \\
*\end{array}$ & & $\begin{array}{l}23 \cdot 9 \pm 1 \cdot 6 \\
*\end{array}$ & $\begin{array}{c}28.5 \pm 2.5 \\
*\end{array}$ & $\begin{array}{c}34.5 \pm 1.9 \\
*\end{array}$ & $\begin{array}{c}27.7 \pm 0.6 \\
*\end{array}$ & $\begin{array}{c}26.4 \pm 0.6 \\
*\end{array}$ \\
\hline DD & $31 \cdot 3 \pm 1 \cdot 3$ & & $29.9 \pm 0.8$ & * $\quad 38.6 \pm 0.9$ & * $41.7 \pm 0.6$ & $* \quad 35.0 \pm 3.5$ & $38.4 \pm 0.7$ \\
\hline
\end{tabular}

Total lipid (mg/g wet wt)

\begin{tabular}{|c|c|c|c|c|c|c|}
\hline $\mathbf{D E}+\mathbf{I S}$ & $38 \cdot 8 \pm 17 \cdot 2$ & $\begin{array}{c}102 \pm 16 \\
*\end{array}$ & $\begin{array}{c}* 144 \pm 15 \\
*\end{array}$ & $\begin{array}{c}172 \pm 17 \\
*\end{array}$ & $\begin{array}{c}159 \pm 13 \\
*\end{array}$ & $\underset{*}{153} \pm 10$ \\
\hline Caput & $48 \cdot 8 \pm 2 \cdot 3$ & $60 \cdot 8 \pm 0.5$ & $\begin{array}{c}78.0 \pm 1.6 \\
*\end{array}$ & $52 \cdot 4 \pm 4 \cdot 7$ & 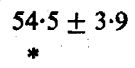 & $39 \cdot 3 \pm 1 \cdot 7$ \\
\hline Cauda & $20.8 \pm 0.4$ & $38.1 \pm 0.9$ & $26 \cdot 3 \pm 0.4$ & $\begin{array}{l}33.0 \pm 1.9 \\
*\end{array}$ & $\begin{array}{c}31 \cdot 8 \pm 1 \cdot 0 \\
*\end{array}$ & $22 \cdot 0 \pm 0.3$ \\
\hline DD & $34 \cdot 3 \pm 10 \cdot 4$ & $38 \cdot 4 \pm 1 \cdot 0$ & $36 \cdot 0 \pm 4 \cdot 1$ & $54.9 \pm 7.9$ & $69 \cdot 5 \pm 7 \cdot 8$ & * $\quad 42.9 \pm 2.2$ \\
\hline
\end{tabular}

\begin{tabular}{|c|c|c|c|c|c|c|c|c|}
\hline \multicolumn{9}{|c|}{ Phospholipid (mg/g wet wt) } \\
\hline $\mathrm{DE}+\mathrm{IS}$ & $12 \cdot 8 \pm 0.7$ & $* \quad 16.6 \pm 2.5$ & $*$ & $12 \cdot 3 \pm 0 \cdot 9$ & $*$ & $14 \cdot 9 \pm 0.6$ & $14 \cdot 2 \pm 0 \cdot 6$ & $\begin{array}{c}14 \cdot 4 \pm 0.7 \\
*\end{array}$ \\
\hline Caput & $12 \cdot 5 \pm 0 \cdot 5$ & $* \quad 17 \cdot 0 \pm 0 \cdot 2$ & $*$ & $13 \cdot 4 \pm 0 \cdot 7$ & & $15 \cdot 3 \pm 0 \cdot 5$ & * $13.4 \pm 0.5$ & $\begin{array}{c}* 17 \cdot 2 \pm 1 \cdot 0 \\
*\end{array}$ \\
\hline Cauda & $11 \cdot 6 \pm 0.2$ & $* \quad 15.7 \pm 0.5$ & & $13 \cdot 6 \pm 0 \cdot 1$ & * & $\begin{array}{c}15 \cdot 5 \pm 0.4 \\
*\end{array}$ & $\begin{array}{l}14 \cdot 8 \pm 0 \cdot 6 \\
*\end{array}$ & $14 \cdot 3 \pm 0 \cdot 3$ \\
\hline DD & $12 \cdot 6 \pm 0 \cdot 2$ & $13 \cdot 6 \pm 0 \cdot 5$ & & $12 \cdot 0 \pm 0.6$ & & $12 \cdot 1 \pm 0 \cdot 2$ & $9 \cdot 3 \pm 0 \cdot 1$ & $10 \cdot 6 \pm 0 \cdot 2$ \\
\hline \multicolumn{9}{|c|}{ DNA (mg/g wet wt) } \\
\hline $\mathrm{DE}+\mathrm{IS}$ & $\begin{array}{l}5.25 \pm 0.06 \\
*\end{array}$ & $\begin{array}{c}2.44 \pm 0.04 \\
*\end{array}$ & & $\begin{array}{l}2.63 \pm 0.04 \\
*\end{array}$ & $*$ & $\begin{array}{l}1.65 \pm 0.06 \\
*\end{array}$ & $\begin{array}{l}1.56 \pm 0.06 \\
*\end{array}$ & $\begin{array}{l}1.40 \pm 0.06 \\
*\end{array}$ \\
\hline Caput & $6.07 \pm 0.55$ & $* \quad 3.75 \pm 0.04$ & * & $\begin{array}{l}2 \cdot 15 \pm 0.07 \\
*\end{array}$ & & $2 \cdot 48 \pm 0 \cdot 10$ & $\begin{array}{l}2.28 \pm 0.07 \\
*\end{array}$ & $\begin{array}{c}1.98 \pm 0.08 \\
*\end{array}$ \\
\hline Cauda & $\begin{array}{c}6.21 \pm 0.09 \\
*\end{array}$ & $\begin{array}{c}3.81 \pm 0.45 \\
*\end{array}$ & * & $\begin{array}{c}3.06 \pm 0.02 \\
*\end{array}$ & & $\begin{array}{l}2 \cdot 71 \pm 0.10 \\
*\end{array}$ & $\begin{array}{l}2 \cdot 75 \pm 0 \cdot 12 \\
*\end{array}$ & $\begin{array}{c}2.94 \pm 0.07 \\
*\end{array}$ \\
\hline DD & $4.51 \pm 0.06$ & $* 3.30 \pm 0.09$ & $*$ & $2 \cdot 64 \pm 0.38$ & * & $1.56 \pm 0.05$ & $1 \cdot 25 \pm 0.05$ & $1 \cdot 19 \pm 0.03$ \\
\hline
\end{tabular}


Table 1-continued

\begin{tabular}{|c|c|c|c|c|c|c|}
\hline & \multicolumn{6}{|c|}{ Age (days) } \\
\hline & 19 & 36 & 48 & 60 & 90 & 120 \\
\hline \multicolumn{7}{|c|}{ RNA (mg/g wet wt) } \\
\hline $\mathrm{DE}+\mathrm{IS}$ & $4 \cdot 91 \pm 0 \cdot 11$ & $5 \cdot 33 \pm 0 \cdot 65$ & * $3.55 \pm 0.07$ & $3.65 \pm 0.21$ & $3 \cdot 37 \pm 0 \cdot 19$ & $\begin{array}{l}3 \cdot 30 \pm 0.13 \\
*\end{array}$ \\
\hline Caput & $5 \cdot 33 \pm 0 \cdot 15$ & $5 \cdot 60 \pm 0$ & $\begin{array}{c}* 3.84 \pm 0.05 \\
*\end{array}$ & $\begin{array}{c}4 \cdot 02 \pm 0 \cdot 16 \\
*\end{array}$ & $* 3.40 \pm 0.13$ & $\begin{array}{c}* \quad 3.81 \pm 0.10 \\
*\end{array}$ \\
\hline Cauda & $\begin{array}{l}4.96 \pm 0.04 \\
*\end{array}$ & $\begin{array}{c}* 5.77 \pm 0.04 \\
*\end{array}$ & $\begin{array}{c}* \quad 4.72 \pm 0.05 \\
*\end{array}$ & $\begin{array}{c}4 \cdot 43 \pm 0 \cdot 15 \\
*\end{array}$ & $\begin{array}{c}* \quad 3 \cdot 18 \pm 0.08 \\
*\end{array}$ & $\begin{array}{l}3 \cdot 41 \pm 0 \cdot 10 \\
*\end{array}$ \\
\hline DD & $4 \cdot 23 \pm 0.09$ & * $3.67 \pm 0.04$ & $* \quad 3.07 \pm 0.18$ & $2 \cdot 85 \pm 0 \cdot 10$ & * $2.37 \pm 0.07$ & * $2.87 \pm 0.12$ \\
\hline \multicolumn{7}{|c|}{ Acid-soluble phosphorus (mg/g wet wt) } \\
\hline $\mathrm{DE}+\mathrm{IS}$ & $0.745 \pm 0.070$ & $0.688 \pm 0.086$ & $\begin{array}{l}0.612 \pm 0.014 \\
*\end{array}$ & $\begin{array}{l}0.679 \pm 0.026 \\
*\end{array}$ & $\begin{array}{l}0.640 \pm 0.024 \\
*\end{array}$ & $\begin{array}{l}0.640 \pm 0.017 \\
*\end{array}$ \\
\hline Caput & $0.758 \pm 0.028$ & $0.955 \pm 0.006$ & $\begin{array}{l}* 1 \cdot 22 \pm 0 \cdot 10 \\
*\end{array}$ & $1.46 \pm 0.03$ & $1.42 \pm 0.04$ & $* \quad 1.82 \pm 0.21$ \\
\hline Cauda & $0.720 \pm 0.009$ & $0.827 \pm 0.031$ & $0.809 \pm 0.025 *$ & $\begin{array}{l}1.45 \pm 0.03 \\
*\end{array}$ & $\begin{array}{l}1 \cdot 60 \pm 0.04 \\
*\end{array}$ & $\begin{array}{c}* \quad 1.99 \pm 0.10 \\
*\end{array}$ \\
\hline DD & $0.825 \pm 0$ & $0.836 \pm 0.021$ & $0.902 \pm 0.030$ & $1.07 \pm 0.02$ & $1.00 \pm 0.05$ & $1 \cdot 10 \pm 0.03$ \\
\hline \multicolumn{7}{|c|}{ Glycogen (mg/g wet wt) } \\
\hline $\mathrm{DE}+\mathrm{IS}$ & $0.76 \pm 0.14$ & $\begin{array}{c}* 1.23 \pm 0.06 \\
*\end{array}$ & $\begin{array}{c}* 0.82 \pm 0.12 \\
*\end{array}$ & $\begin{array}{l}0 \cdot 88 \pm 0 \cdot 16 \\
*\end{array}$ & $0.82 \pm 0.05$ & $0.78 \pm 0.14$ \\
\hline Caput & $0 \cdot 78 \pm 0 \cdot 11$ & * $\quad 1.84 \pm 0.14$ & $\begin{array}{c}* 1.29 \pm 0.08 \\
*\end{array}$ & $\begin{array}{l}1 \cdot 16 \pm 0 \cdot 10 \\
*\end{array}$ & $1.09 \pm 0.03$ & $1.02 \pm 0.07$ \\
\hline Cauda & $\begin{array}{c}1.05 \pm 0.08 \\
*\end{array}$ & $1.93 \pm 0.05$ & $1.68 \pm 0.07$ & $1.64 \pm 0.06$ & $\begin{array}{l}1 \cdot 32 \pm 0.03 \\
*\end{array}$ & $\begin{array}{l}1.31 \pm 0.07 \\
*\end{array}$ \\
\hline DD & $1.96 \pm 0.07$ & $1.99 \pm 0.12$ & $1 \cdot 76 \pm 0.04$ & $1 \cdot 70 \pm 0.14$ & $1.90 \pm 0.07$ & $1.92 \pm 0.16$ \\
\hline \multicolumn{7}{|c|}{ Sialic acid $(\mu \mathrm{mol}$ NANA/g wet wt) } \\
\hline $\mathrm{DE}+\mathrm{IS}$ & $1 \cdot 28 \pm 0 \cdot 10$ & $1 \cdot 46 \pm 0.07$ & $\begin{array}{c}1.44 \pm 0.02 \\
*\end{array}$ & $1 \cdot 28 \pm 0 \cdot 03$ & $\begin{array}{l}1 \cdot 18 \pm 0.03 \\
*\end{array}$ & $1 \cdot 28 \pm 0 \cdot 02$ \\
\hline Caput & $1.07 \pm 0.16$ & $\begin{array}{c}* \quad 1 \cdot 50 \pm 0.13 \\
*\end{array}$ & $1.69 \pm 0.03$ & $\begin{array}{c}1.49 \pm 0.04 \\
*\end{array}$ & $\begin{array}{l}1 \cdot 34 \pm 0.10 \\
*\end{array}$ & $\begin{array}{l}1.35 \pm 0.03 \\
*\end{array}$ \\
\hline Cauda & $1 \cdot 04 \pm 0 \cdot 10$ & $* \quad 1.80 \pm 0.09$ & $\begin{array}{c}1.89 \\
*\end{array}$ & $\begin{array}{c}2.09 \\
*\end{array}$ & $\begin{array}{c}2 \cdot 21 \pm 0 \cdot 11 \\
*\end{array}$ & $\begin{array}{l}2.09 \pm 0.02 \\
*\end{array}$ \\
\hline DD & $1.06 \pm 0.10$ & $* \quad 1.68 \pm 0.06$ & $* \quad 1.43 \pm 0.04$ & $1 \cdot 39 \pm 0.03$ & $1.43 \pm 0.07$ & $1.57 \pm 0.06$ \\
\hline
\end{tabular}

The values represent the Means \pm S.E.M. of four determinations in most instances. Significant differences $(P<0.05)$ between adjacent means are indicated by an asterisk, although higher levels of significance were found between some means. DE+IS, ductuli efferentes plus initial segment; caput, caput epididymidis; cauda, cauda epididymidis; DD, ductus deferens.

The levels of calcium and magnesium in adult rat tissues are shown in Table 3. An analysis of variance indicated that there were no significant differences between the tissues studied with respect to the concentration of these two metals.

The results of the determination of spermine and spermidine are also presented in Table 3 . Lowest levels of spermine were found in the caput $(P<0.05)$ and the testis, cauda and caput all contained lower levels of spermine than the liver $(P<0.001)$ which in turn had a considerably lower concentration than the prostate $(P<0.001)$. The testis and cauda had a lower concentration of spermidine than the caput or liver $(P<0.001)$ whilst the concentration in the prostate was $>\times 10$ that in any of the other tissues. Total polyamine was lowest in the testis and cauda; significantly higher levels were present in the caput, liver and prostate in that order $(P<0.001)$. 
Table 2. The biochemical composition of the testis, bladder and liver in adult rats

\begin{tabular}{lccc}
\hline & Testis & Bladder & Liver \\
\hline Dry weight (\%) & $13.8 \pm 0.1$ & $20.7 \pm 0.6$ & $31.2 \pm 0.7$ \\
Total protein (mg/g wet wt) & $93.8 \pm 1 \cdot 5$ & $174 \pm 2$ & $207 \pm 4$ \\
Soluble protein (\% total protein) & $38.9 \pm 0.5$ & $23.3 \pm 1.0$ & $34.7 \pm 1.5$ \\
Total lipid (mg/g wet wt) & $20.0 \pm 0.5$ & $19.0 \pm 0.6$ & $63.8 \pm 7.8$ \\
Phospholipid (mg/g wet wt) & $13.7 \pm 0.2$ & $5.85 \pm 0.65$ & $32.4 \pm 0.5$ \\
DNA (mg/g wet wt) & $1.56 \pm 0.08$ & $1.61 \pm 0.04$ & $1.59 \pm 0.09$ \\
RNA (mg/g wet wt) & $1.99 \pm 0.10$ & $1.88 \pm 0.14$ & $9.62 \pm 0.40$ \\
Acid-soluble phosphorus (mg/g wet wt) & $0.722 \pm 0.011$ & $0.677 \pm 0.028$ & $1.13 \pm 0.03$ \\
Glycogen (mg/g wet wt) & $0.23 \pm 0.02$ & $1.45 \pm 0.12$ & $35.6 \pm 3.1$ \\
Sialic acid ( $\mu$ mol NANA/g wet wt) & $1.33 \pm 0.08$ & $1.68 \pm 0.02$ & $1.06 \pm 0.04$ \\
& & & \\
\hline
\end{tabular}

Values represent the Means \pm S.E.M. of four determinations.

Table 3. The calcium, magnesium, spermine and spermidine concentrations in the tissues of the excurrent duct system of the testis and other organs of the adult rat

\begin{tabular}{|c|c|c|c|c|c|}
\hline & Calcium & $\begin{array}{l}\text { Magnesium } \\
\text { (mM) }\end{array}$ & $\begin{array}{c}\text { Spermine } \\
(\mu \mathrm{mol} / \mathrm{g} \text { wet wt })\end{array}$ & $\begin{array}{c}\text { Spermidine } \\
(\mu \mathrm{mol} / \mathrm{g} \text { wet wt })\end{array}$ & $\begin{array}{l}\text { Total polyamine } \\
(\mu \mathrm{mol} / \mathrm{g} \text { wet wt) }\end{array}$ \\
\hline Testis & & & $0.461 \pm 0.025$ & $0.247 \pm 0.014$ & $0.707 \pm 0.039$ \\
\hline $\begin{array}{l}\text { Ductuli efferentes plus } \\
\text { initial segment }\end{array}$ & $1.64 \pm 0.14$ & $4 \cdot 56 \pm 0 \cdot 12$ & & & \\
\hline Caput epididymidis & $1 \cdot 20 \pm 0 \cdot 10$ & $6.05 \pm 0.53$ & $0.381 \pm 0.011$ & $0.764 \pm 0.046$ & $1.08 \pm 0.04$ \\
\hline Cauda epididymidis & $1.29 \pm 0.13$ & $6.16 \pm 0.03$ & $0.416 \pm 0.022$ & $0.372 \pm 0.040$ & $0.788 \pm 0.054$ \\
\hline Ductus deferens & $1.80 \pm 0.36$ & $7.48 \pm 0.96$ & & & \\
\hline Liver & $1 \cdot 11 \pm 0.07$ & $5 \cdot 38 \pm 1 \cdot 23$ & $0.784 \pm 0.017$ & $0.691 \pm 0.062$ & $1.48 \pm 0.05$ \\
\hline Prostate & & & $4 \cdot 18 \pm 0.03$ & $9 \cdot 62 \pm 1 \cdot 10$ & $13 \cdot 8 \pm 1 \cdot 1$ \\
\hline
\end{tabular}

The results represent the Means \pm S.E.M. of analyses from three rats. Total polyamine represents the sum of spermine and spermidine.

\section{Discussion}

An analysis of a tissue as a whole represents the mean of all the cell types and fluid spaces in the tissue. Although assessment by this type of analysis is limited, a useful comparison can be made between different segments of an organ and also between the same segment at different developmental stages. In addition to the EDS, adult testis, bladder and liver were also analysed for purposes of comparison and to act as a check that the analyses yielded results similar to those reported previously. For this purpose the analytical data collected for liver by Knox (1972) was particularly useful and the bladder was chosen as a tissue consisting principally of smooth muscle for comparison with the DD.

In general, the results of the analyses were similar to those of comparable previous studies (Schmidt \& Thannhauser, 1945; Schneider, 1945; Warren, 1959; Scott, Dawson \& Rowlands, 1963; Ewing, Means, Beames \& Montgomery, 1966; Fournier, 1966; Peyre \& Laporte, 1966; Rajalakshmi \& Prasad, 1968, 1969, 1971; Kar et al., 1968; Johnson, 1970; Turner \& Johnson, 1971; Knox, 1972; Riar, Setty \& Kar, 1973). The DNA levels were, however, slightly lower than those of previous reports (Fujii \& Koyama, 1962; Desjardins, MacMillan \& Hafs, 1968; Knox, 1972).

The immature EDS at 19 days is rather similar along its length with respect to its biochemical composition. The DD shows some differences, such as more soluble protein and glycogen reflecting its greater proportion of smooth muscle. As the animal matures, however, biochemical differences become more marked between different segments of the duct system. The DE+IS becomes associated with a much greater content of lipid whilst the caput and cauda develop a higher concentration of acid-soluble phosphorus and sialic acid. Although maturation of the caput and cauda is associated 
with a substantial increase in the amount of fluid present in the epididymal lumen, this was not accompanied by any marked decrease in their dry weight.

All segments of the EDS showed a decline in protein content during prepubertal development from 19 to 48 days, but showed little change during subsequent maturation. This may refiect the accumulation of a low-protein fluid in the duct before puberty; as the duct matures more protein might be expected to pass into the lumen due to the secretory activity of the epithelium. The DNA content of the immature EDS is also great in comparison with adult tissues. The dramatic decrease in DNA content during maturation indicates that the increase in organ size was due to an increase in cell size rather than cell number.

Glycogen levels in the EDS were considerably higher than in the testis and showed a progressive increase along the length of the EDS consistent with the increase in the proportion of smooth muscle. The substantial increase in glycogen in the DE+IS, caput and cauda during the prepubertal (Days 19 to 36 ) stage may indicate that the epithelium is acquiring energy reserves in preparation for subsequent synthetic activity.

Sialic acid levels in the epididymis are not vastly different from those found in other tissues. However, the rise in sialic acid which occurs in all segments of the EDS except the DE+IS during the prepubertal period indicates direct synthesis by the epididymis, for although the sperm acrosome is rich in sialic acid (Hartree \& Srivastava, 1965) and would contribute to sialic acid levels in the testis, spermatozoa do not enter the epididymis until puberty.

Determinations of calcium, magnesium and polyamines were made as a result of observations recorded during the isolation of separated epithelial cells from the epididymis (D. E. Brooks, unpublished work) in which it was noted that crystals appeared during tissue digestion in a Ringerphosphate medium. It was first suspected that the crystals might be calcium phosphate but an analysis indicated that levels of calcium were not unusually high in the epididymis, although quite high levels have been reported in fluid from the cauda of the bull and boar (Crabo, 1965; Einarsson, 1971). Nevertheless, the amount of calcium present would not have been sufficient to cause formation of insoluble calcium phosphate.

An additional possibility existed that the crystals were Boettcher's crystals of spermine phosphate (Mann, 1964). The morphology of the crystals was similar to those photographed by Rosenheim (1924). The prostatic secretion is the origin of spermine in human seminal plasma, and the rat prostate also contains high levels of spermine and spermidine (Rosenthal \& Tabor, 1956). Determinations of spermine and spermidine in testis, liver and prostate confirmed the values reported by Rosenthal \& Tabor (1956). The levels in the epididymis were similar to testicular levels but considerably below those of the prostate. Epididymal spermatozoa are reported to contain spermidine, but not the enzymes necessary for its formation (MacIndoe \& Turkington, 1973), although the epididymis as a whole does contain these enzymes (Majumder, MacIndoe \& Turkington, 1974). It has been suggested that polyamines function to stabilize enzymes, nucleic acid and membranes. It is therefore possible that spermine and spermidine are acting in the epididymis to stabilize spermatozoa during their transport and storage before ejaculation.

This study was supported by the Australian Research Grants Committee. I am also grateful to Ms C. J. Lumma for technical assistance and Mrs G. Bishop for conducting the statistical analyses.

\section{References}

Bligh, E.G. \& DYER, W.J. (1959) A rapid method of total lipid extraction and purification. Can. $J$. Biochem. Physiol. 37, 911-917.

Bose, A.R., Kar, A.B. \& Dasgupta, P.R. (1966) Sialic acid in the genital organs of the male rat. Current Sci. 35, 13-14.

Brooks, D.E., Hamilton, D.W. \& Mallek, A.H. (1974) Carnitine and glycerylphosphorylcholine in the reproductive tract of the male rat. J. Reprod. Fert. 36, 141-160.
Chen, P.S., Toribara, T.Y. \& Warner, H. (1956) Microdetermination of phosphorus. Analyt. Chem. 28, 1756-1758.

CONCHIE, J. \& MANN, T. (1957) Glycosidases in mammalian sperm and seminal plasma. Nature, Lond. 179, 1190-1191.

Conchie, J., Findlay, J. \& Levvy, G.A. (1959) Mammalian glycosidases. Distribution in the body. Biochem. J. 71, 318-325.

Crabo, B. (1965) Studies on the composition of epi- 
didymal content in bulls and boars. Acta vet. scand. 6, Suppl. 5.

Dawson, R.M.C. \& Rowlands, I.W. (1959) Glycerylphosphorylcholine in the male reproductive organs of rats and guinea-pigs. Q.Jl exp. Physiol. 44, 26-34.

Dawson, R.M.C., MANN, T. \& WhITE, I.G. (1957) Glycerylphosphorylcholine and phosphorylcholine in semen, and their relation to choline. Biochem. $J$. 65, 627-634

Desjardins, C., MacMillan, K.L. \& Hafs, H.D. (1968) Reproductive organ DNA and RNA of male and female rats from birth to 100 days of age. Anat. Rec. 161, 17-22.

DruRY, H.F. (1948) Identification and estimation of pentoses in the presence of glucose. Archs Biochem. Biophys. 19, 455-466.

EinARSSON, S. (1971) Studies on the composition of epididymal content and semen in the boar. Acta vet. scand. Suppl. 36.

Ewing, L.L., Means, A.R., Beames, C.G. \& MontGOMERY, R.D. (1966) Biochemical changes in rat testis during postnatal maturation. J. Reprod. Fert. 12, 295-307.

FouRnier, S. (1966) Répartition de l'acide sialique dans l'appareil génital du rat Wistar adulte normal et castré. C. r. Séanc. Soc. Biol. 160, 1087-1090.

French, F.S. \& Ritzén, E.M. (1973) A high-affinity androgen-binding protein (ABP) in rat testis: evidence for secretion into efferent duct fluid and absorption by epididymis. Endocrinology 93, 88-95.

Fuji, T. \& Koyama, R. (1962) Nucleic acid contents of various organs in rats during postnatal growth. Endocr. jap. 9, 66-73.

GILes, K.W. \& MYers, A. (1965) An improved diphenylamine method for the estimation of deoxyribonucleic acid. Nature, Lond. 206, 93.

Hartree, E.F. \& Srivastava, P.N. (1965) Chemical composition of the acrosomes of ram spermatozoa. J. Reprod. Fert. 9, 47-60.

JoHnson, A.D. (1970) Testicular lipids. In The Testis, Vol. II, pp. 193-258. Eds A. D. Johnson, W. R. Gomes \& N. L. VanDemark. Academic Press, New York.

Kar, A.B., Jehan, Q., Kamboj, V.P., ChowdhuRY, S.R. \& CHOWDHURY, A.R. (1968) Effect of busulphan on biochemical composition of rat seminiferous tubules. Ind. J. exp. Biol. 6, 9-12.

KNox, W.E. (1972) Enzyme Patterns in Fetal, Adult and Neoplastic Rat Tissues. S. Karger, Basel.

Levine, N. \& Marsh, D.J. (1971) Micropuncture studies of the electrochemical aspects of fluid and electrolyte transport in individual seminiferous tubules, the epididymis and the vas deferens in rats. J. Physiol., Lond. 213, 557-570.

LOWRY, O.H., Rosebrough, N.J., Farr, A.L. \& RANDALL, R.J. (1951) Protein measurement with the Folin phenol reagent. J. biol. Chem. 193, 265-275.

MACINDOE, J.H. \& TURKINGTON, R.W. (1973) Hormonal regulation of spermidine formation during spermatogenesis in the rat. Endocrinology 92, 595-605.

MAJUmder, G.C., Macindoe, J.H. \& Turkington, R.W. (1974) Hormonal control of ornithine decarboxylase and S-adenosyl-L-methionine decarboxylase during development of the rat epididymis. Life Sci, 15, 45-55.
ManN, T. (1964) The Biochemistry of Semen and of the Male Reproductive Tract. Methuen, London.

Marquis, N.R. \& FriTz, I.B. (1965) Effects of testosterone on the distribution of carnitine, acetylcarnitine, and carnitine acetyltransferase in tissues of the reproductive system of the male rat. $J$, biol. Chem. 240, 2197-2200.

Munro, H.N. \& Fleck, A. (1966) The determination of nucleic acids. Meth. biochem. Analysis 14, 113-176.

ORGEBIN-CRIST, M.-C. (1973) Maturation of spermatozoa in the rabbit epididymis: effect of castration and testosterone replacement. J. exp. Zool. 185, 301-309.

PegG, A.E., Lockwood, D.H. \& Williams-Ashman, H.G. (1970) Concentrations of putrescine and polyamines and their enzymic synthesis during androgen-induced prostatic growth. Biochem. $J$. 117, 17-31.

Pfyre, A. \& LaporTe, P. (1966) Évolution des acides sialiques épididymaires chez le rat impubère et adulte. C. r. hebd. Séanc. Acad. Sci., Paris 263, 1872-1875.

RaINA, A. (1963) Studies on the determination of spermidine and spermine and their metabolism in the developing chick embryo. Acta physiol. scand. 60, Suppl. 218.

Rajalakshmi, M. \& Prasad, M.R.N. (1968) Changes in the sialic acid content of the accessory glands of the male rat. J. Endocr. 41, 471-476.

Rajalakshmi, M. \& Prasad, M.R.N. (1969) Changes in sialic acid in the testis and epididymis of the rat during the onset of puberty. $J$. Endocr. 44, 379-385.

Rajalakshmi, M. \& Prasad, M.R.N. (1971) Alterations in sialic acid in the epididymis of the puberal rat in response to changes in functional activity of the testis. $J$. Reprod. Fert. 24, 409-413.

Riar, S.S., SetTy, B.S. \& Kar, A.B. (1973) Studies on the physiology and biochemistry of mammalian epididymis: biochemical composition of epididymis. A comparative study. Fert. Steril. 24, 355-363.

Rosenheim, O. (1924) The isolation of spermine phosphate from semen and testes. Biochem. J. 18, 12531262.

RoSENTHAL, S.M. \& TABOR, C.W. (1956) The pharmacology of spermine and spermidine. Distribution and excretion. J. Pharm. exp. Ther. 116, 131-138.

SChmidt, G. \& Thannhauser, S.J. (1945) A method for the determination of desoxyribonucleic acid, ribonucleic acid, and phosphoproteins in animal tissues. J. biol. Chem. 161, 83-89.

SchneIder, W.C. (1945) Phosphorus compounds in animal tissues. 1. Extraction and estimation of desoxypentose nucleic acid and of pentose nucleic acid. J. biol. Chem. 161, 293-303.

ScotT, T.A. \& Melvin, E.H. (1953) Determination of dextran with anthrone. Analyt. Chem. 25, 1656-1661.

ScotT, T.W., Dawson, R.M.C. \& Rowlands, I.W. (1963) Phospholipid inter-relationships in rat epididymal tissue and spermatozoa. Biochem. $J$. 87, 507-512.

TURner, P.C. \& Johnson, A.D. (1971) Epididymal lipid of the rat with and without testicular contribution. J. Reprod. Fert. 27, 249-255.

WARREN, L. (1959) The thiobarbituric acid assay of sialic acids. J. biol. Chem. 234, 1971-1975. 